\title{
DEVELOPMENT OF A LOW-COST ICEBOX FOR PRESERVATION AND TRANSPORTATION OF ICED FISH
}

\author{
A. K. M. Nowsad, M. R. Islam and F. H. Shikha \\ Department of Fisheries Technology, Bangladesh Agricultural University \\ Mymensingh-2202, Bangladesh
}

\begin{abstract}
A low-cost icebox was developed and its efficacy in icing fish was evaluated in order to minimize huge post-harvest loss and ensure adequate price of wet fish through quality maintenance. Traditional bamboo basket capable of containing 25-30 kg fresh fish was wrapped inside, bottom and top twice by polythene gunny sacs. In between the two layers of gunny sacs, a layer of plant leave mat (hogla mat) and a layer of old nylon net/cloths were placed for insulation. A small plastic pipe (1 cm diameter, $60 \mathrm{~cm}$ long) was inserted through the bottom to drain out melted water. The rear end of the pipe was kept fasten with the rim of the basket. To keep the iced fish inside of the wrapped basket, a separate plain polythene sheet was used. Freshly caught Puntius sophore $(5.8 \pm 0.4 \mathrm{~cm})$ and Cirrhinus mrigala $(16.4 \pm 1.3 \mathrm{~cm})$ were preserved under adequate icing for 7 to 10 days. Temperature of the iced fish inside was maintained between $0.4^{\circ}$ to $3.1^{\circ} \mathrm{C}$. Freshness of the fish kept in the new icebox during preservation and transportation was investigated through sensory and biochemical methods. No chance of secondary contamination was found in new ice box because the fish could not come in contact of the basket materials. The device was very easy to clean and keep clean. Shape of filled icebox was found regular and stout with no sign of breakage and leakage. Rate of melting of ice was $23.0 \pm 1.6 \%$ in 24 hours. Replacement of ice was done at such rate. Melted water was adequately drained out. Iced C. mrigala and P. sophore kept in the icebox were in excellent quality in terms of both sensory and biochemical indicators till the end of $7^{\text {th }}$ or $10^{\text {th }}$ day, respectively. The study suggested that the new icebox was effective in preserving and transporting iced fish.
\end{abstract}

Key words : Wet fish, Ice, Low-cost ice box, Preservation, Fresh fish, Quality

\section{INTRODUCTION}

Fisheries sector in Bangladesh has been entrapped with huge post harvest loss every year due to ignorance and negligence of the people in different stages from the primary producers, transporters, laborers, retailers, artisanal small and large scale processors, consumers, law enforcing agencies to the government. In Bangladesh, fish markets take daily deliveries of fresh fish from fish landing centers, farms and ponds, those are generally many hundreds of kilometers away. Traditionally, fish are packed without or with nominal ice in bamboo basket or gunny sacs wrapped by polythene sheets with no insulation. Under inadequate icing conditions melting of ice is very high. As a result, the quality of fish is deteriorated during transportation and preservation of fish, that also 
reduces the market price of fish. Study suggested that under inadequate icing the fish produced by the "Daudkandi Flood Plain Fisheries" were sold at 30-50\% lesser price in Chittagong fish market (Nowad, 2007). Survey revealed that about $30 \%$ of the country's harvested fish loses most of its quality before reaching to the consumers due to lack of adequate icing and icebox (Nowsad, 2005). The loss accounts for about Tk. 9,000 cores in each year (Nowsad, 2007). To minimize such huge loss and to ensure adequate price of wet fish in domestic market through quality maintenance, a suitable icebox is required to be developed. The icebox should be effective in maintaining the freshness of iced fish, suitable for rural level use and at the same time, should be affordable by the poor fishers and fish traders. Considering these challenges, the study was undertaken to develop an icebox using locally available low-cost materials and the effectiveness of the icebox was tested in field situation for a year.

\section{MATERIALS AND METHODS}

\section{Preparation of low cost icebox}

Bamboo basket generally used for transporting fish or other agricultural materials was modified and developed to construct a low-cost icebox. A fine woven split bamboo basket capable of containing $25-30 \mathrm{~kg}$ fresh fish was taken. Inside walls of the basket were wrapped with one layer polythene gunny sac in such way that the extended portion of the gunny sac remained beyond the upper edge of the basket. An adequate cut piece of a mat of plant leaves, hogla, was placed inside of the basket (on the first layer of gunny sac) to cover the whole area (Plate 1). A layer of old nylon cloth or abandoned monofilament net was placed on hogla layer. Another layer of equal size of polythene gunny sac was put on hogla/nylon cloth layer and these 3 layers of wrapping materials (one layer hogla/cloth in between two layers of gunny sac ) were stitched together with nylon twine to the basket so that all wrapping materials remained fixed within the basket (Plate 2).

\section{Icing of fish}

Freshly caught $P$. sophore $(5.8 \pm 0.4 \mathrm{~cm})$ and C. mrigala $(16.4 \pm 1.3 \mathrm{~cm})$ were preserved with adequate icing for 10 days. An additional plain polythene sheet was placed inside the wrapped basket to make a sac to hold iced fish. This additional sheet was washed and reused after each operation. Before icing, the fishes were adequately washed with running tap water to remove filth from fish body. Ice was properly crushed and placed at the bottom of the basket at a layer of about 3 inch. Ice and fish (1:1) was kept alternately in adequate fashion in the polythene sac of the basket so that an ideal icing condition was maintained. Extra layer of ice was used on the top of fish. A small plastic pipe was inserted through the bottom of the basket to pass out melted water.

The pipe was finely tightened with the basket and wrapping materials in the bottom so that it was not misplaced during handling and transport and melted water could not leak out through the contact walls of the pipe and basket. Finally, the extended portions of all wrapping materials (polythene gunny sacs, hogla/cloth and plain polythene sheet/sac) 
were wrapped at the top of the basket. A cover, prepared by same materials, was placed on the top of the basket.

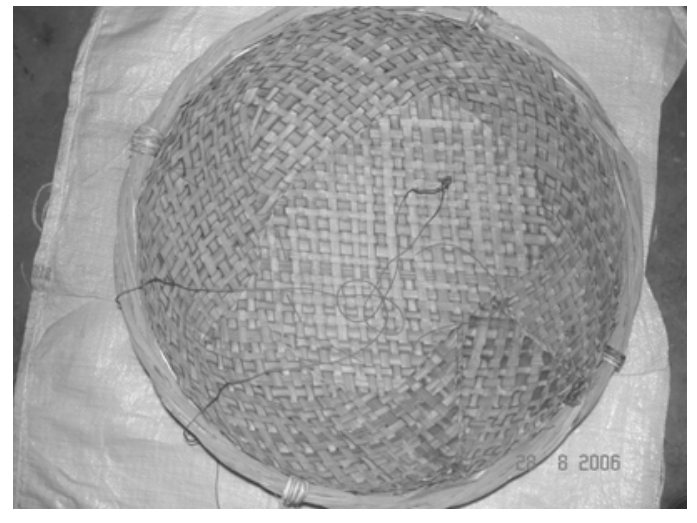

Plate 1. Ice box with a plant leave mat-hogla layer

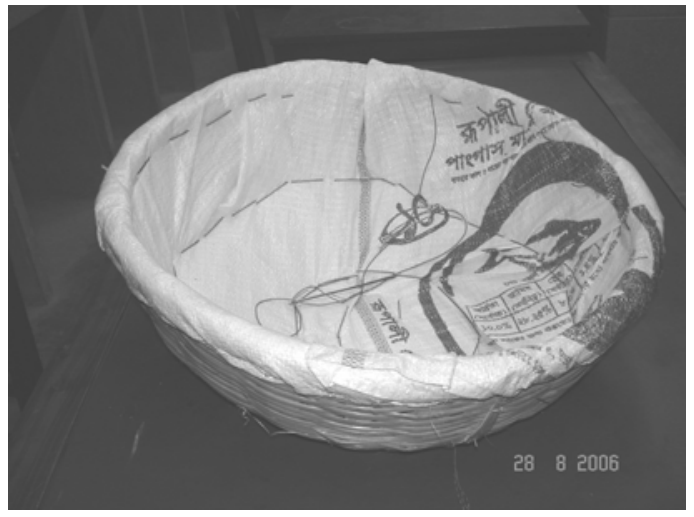

Plate 2. Two layers of gunny sacs stitched together

\section{Study of physical changes of icebox and ice}

Iced fish in the icebox was kept in the laboratory for 7 to 10 days or transported on private vehicles to observe the changes of icebox and fish. Changes in the shape and physical appearance of the icebox were studied during icing, preservation and transportation. Quality of ice inside the icebox was evaluated in terms of changes in colour, rate of melting of ice (\%) and draining rate of melted water (\%). The temperature inside the box was measured with a centigrade thermometer twice in a day, first in the morning at 09:00 hour and the second, in the afternoon at 18:00 hour.

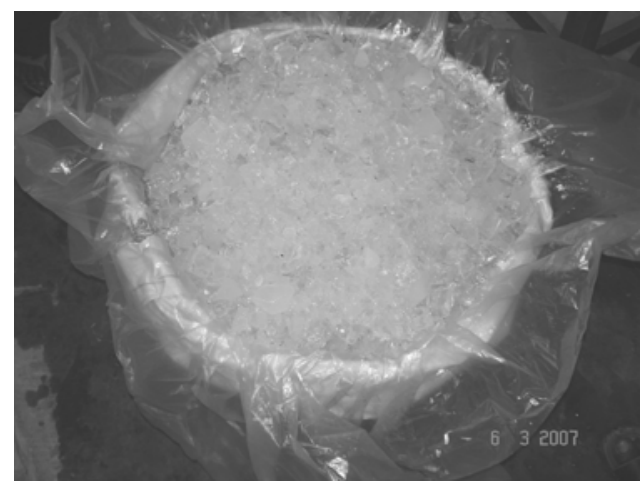

Plate 3. New icebox with iced fish

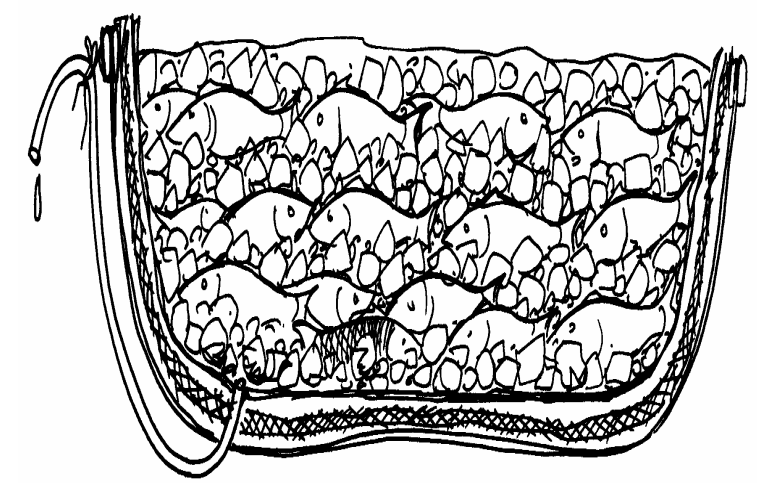

Plate 4. Cross-section of new icebox

\section{Re-icing and draining out of water}

Melted water was drained out at regular intervals and the top layer of ice was replaced at a rate as that of melting of ice. At every 24 hours at 9:00 am, fresh ice was added to the 
top of the fish inside the icebox at the rate of $23 \%$ of the total ice used. However, on the second day, after passing the first 24 hours, a $30 \%$ of the total ice was added. Melted water was taken in a container and the rate of melting was calculated in percent.

\section{Freshness test of iced fish}

Freshness of the iced fish was determined by evaluating organoleptic defect points as described by Howgate et al. (1992). This method was originally proposed for the European Commission (EC) freshness grading of fish and fish products. This test was performed by scoring 7 sensory characters of fish as shown in Table 4. Defect points were calculated from the average scores as shown in Table 1.

Wholesomeness of the iced fish was determined by a 5-person test panel by evaluating the physical appearance, colour and texture of fish on a scale of 0 to 5 with 5 being the best (Table 2).

Table 1. Grading of fish with defect points (DP)

\begin{tabular}{c|c|c}
\hline Grade & DP & Comments \\
\hline A & $<2$ & Excellent/Acceptable \\
B & 2 to $<4$ & Good/Acceptable \\
C & 4 to 5 & Bad/Rejected \\
\hline
\end{tabular}

\section{Biochemical test}

Proximate composition (crude protein, lipid, moisture and ash), non-protein nitrogen (NPN), peroxide value (PV) and total volatile base nitrogen (TVBN) of the iced fish were determined according to the methods of AMC (1979).

\section{Bacteriological test}

Total bacterial count expressed as the colony forming units per gram of fish muscle (cfu/g) was determined by standard plate count on plate count agar according to the dilution technique of Collins and Patricia (1976).

\section{RESULTS AND DISSCUSSION}

\section{Physical conditions of the icebox}

During the present study, the bamboo baskets generally used in wet fish transportation or other domestic purposes throughout the country were modified into insulated icebox (Plates1,2,3 and 4). In the modified baskets fish could not come in contact of the walls of basket, since the side walls were wrapped all along with polyethylene gunny sacs and plain polyethylene sheet. Thus, there was no chance of contamination of fish from the split bamboo that generally harbours bacteria, molds and contaminants (Nowsad, 2005). Obviously, the new device could be able to comply with the fish inspection and quality control regulations put forwarded by the FDA and EU and also by the recent regulations 
of the Bangladesh Government in terms of quality handling and icing of fish (DOF, 2007). The device was very easy to clean and keep clean too.

Several trails were made in the laboratory as well as in the field (Cox's Bazar and Kulierchar) with the beneficiaries to develop, improve and evaluate the efficacy of this new icebox. In the laboratory, fish (Puntius sophore and Cirrhinus mrigala) were preserved for 7- 10 days in the new icebox and various quality parameters of the icebox and the iced fish were tested (Table 2, 3 and 4). Physical conditions of the ice box due to preservation of iced fish were also evaluated (Table 2). The appearance of the box was regular and stout with no sign of leakage for melted water was found. Extra strength was given to the box by supporting with 2 pairs of cross-over bamboo splits fastening throughout inside and outside. This gave sufficient strength to the box to withstand outside pressure and abrasion. The box was found to be dry and clean all along the study period. The pipe inserted through the bottom to drain out melted water was very tightly fastened with the polythene sheet that held fish. Temperature of the ice box and the fish inside was found to vary within $0.4-3.1^{\circ} \mathrm{C}$ range, suggesting that the low-cost icebox was able to keep the fish cool in acceptable cooling range. At every 24 hours at 09:00 am, fresh ice was added to the top of the fish at the rate of $23 \%$ of the total ice used. However, on the second day, after passing a first 24 hours, a $30 \%$ of the total ice was added. This was because of the higher temperature of the fish body that required more ice to cool fish. Except for the first 24 hours, the rate of ice melting was about $23 \pm 1.6 \%$ for the rest of the preservation period tested. The rate of melting, although seemed to be little higher than the ideal icebox, was quite compatible with the insulation mechanism used in this icebox. Ideal icebox generally allows an ice-melting rate of $12-15 \%$ by 24 hours (Nowsad, 2005), because of inbuilt insulation mechanism given by polystyrene/polypropylene walls bridged with thick styrofoam sheet. In the present low-cost ice box, a layer of mat made of thick spongy plant leaves-hogla in between two layers of polythene gunny sacs supported with a layer of old monofilament net gave a good insulation, so that the device allowed only about $23 \%$ melting of ice in a day during summer months. Melted water was more or less adequately drained out through the pipe fixed at the bottom (Table 2).

The wholesomeness of C. mrigala kept in the icebox was checked through sensory methods (Table 2). Fish kept at the top of the box were in excellent quality till the end of $7^{\text {th }}$ day. Fish kept at the bottom of the box, however, lost some colour and wholesomeness, mostly due to prolong subjection to ice-melt water. Small amount of melted water (2-8\%) remained entrapped at the bottom (Table 2) that might cause the fish to lose colour from bright shiny to dull. Further refinement of the box has been done to easy draining out of all melted water.

Quality of iced C. mrigala kept in the icebox was evaluated up to $7^{\text {th }}$ day of storage. The results have been given in Table 3. Proximate composition of the fish were not so changed except little decrement of proteins, lipids and minerals at very slow rate with the lapse of storage time. This was a quite regular phenomenon for ice storage of fish as it lost drip with little amount of nutrient dissolved in it. Both peroxide values and TVB nitrogen values were within acceptable limits till the $5^{\text {th }}$ day of storage. On the $7^{\text {th }}$ day, both the 
values raised up to the margin of safe limit, but still they could be considered good and acceptable for consumption. Several similar trials were made with the new icebox with different fishes. It was observed that in this icebox, adequately pretreated (sorted, cleaned and adequately washed) fish could be kept for 7-8 days without having any deterioration of quality, if a layer of fresh ice was given on the top of fish every after 24 hours.

Table 2. Physical changes of low-cost icebox, ice and iced C. mrigala under different storage period

\begin{tabular}{|c|c|c|c|c|c|c|c|c|c|}
\hline \multirow[t]{2}{*}{ Day } & \multicolumn{3}{|c|}{ Changes in ice box } & \multicolumn{3}{|c|}{ Changes in ice } & \multicolumn{3}{|c|}{ Wholesomeness of fish ${ }^{* 3}$} \\
\hline & $\begin{array}{c}\text { Appeara } \\
\text { nce }\end{array}$ & Condn & $\begin{array}{l}\text { Temp } \\
\left({ }^{\circ} \mathrm{C}\right) \pm S E\end{array}$ & Colour & $\operatorname{RoM}^{* 1}$ & DoMW*2 & $\begin{array}{l}\text { Top } \\
\text { layer }\end{array}$ & $\begin{array}{l}\text { Middle } \\
\text { layer }\end{array}$ & $\begin{array}{l}\text { Bottom } \\
\text { layer }\end{array}$ \\
\hline 0 & $\begin{array}{c}\text { Regular/ } \\
\text { Stout }\end{array}$ & Dry & $\begin{array}{c}- \\
1.1 \pm 0.1\end{array}$ & $\begin{array}{l}\text { Bright } \\
\text { Glassy }\end{array}$ & 0 & 0 & $5.0 \pm 0.0$ & $5.0 \pm 0.0$ & $5.0 \pm 0.0$ \\
\hline 1 & $\begin{array}{c}\text { Regular/ } \\
\text { Stout }\end{array}$ & Dry & $\begin{array}{l}2.0 \pm 0.1 \\
1.2 \pm 0.2\end{array}$ & $\begin{array}{c}\text { Brown/ } \\
\text { Glassy }\end{array}$ & $35 \pm .6$ & $90 \pm .4$ & $4.97 \pm 0.01$ & $4.90 \pm 0.02$ & $4.90 \pm 0.01$ \\
\hline 2 & Regular & Dry & $\begin{array}{l}1.0 \pm 0.2 \\
2.1 \pm 0.3\end{array}$ & Brown & $22 \pm 1.4$ & $98 \pm .6$ & $4.88 \pm 0.01$ & $4.60 \pm 0.11$ & $4.73 \pm 0.21$ \\
\hline 3 & Regular & Dry & $\begin{array}{l}0.4 \pm 0.1 \\
1.8 \pm 0.3\end{array}$ & Brown & $24 \pm 0.8$ & $97 \pm .8$ & $4.88 \pm 0.01$ & $4.40 \pm 0.10$ & $4.30 \pm 0.22$ \\
\hline 4 & Regular & Dry & $\begin{array}{c}1.1 \pm 0.05 \\
2.3 \pm 0.2\end{array}$ & Brown & $22 \pm 1.5$ & $98 \pm .2$ & $4.80 \pm 0.02$ & $4.20 \pm 0.13$ & $4.00 \pm 0.10$ \\
\hline 5 & Regular & Dry & $\begin{array}{l}0.5 \pm 0.2 \\
2.3 \pm 0.2\end{array}$ & Brown & $23 \pm 1.5$ & $98 \pm .8$ & $4.50 \pm 0.04$ & $4.10 \pm 0.26$ & $4.22 \pm 0.12$ \\
\hline 6 & Regular & Dry & $\begin{array}{l}1.0 \pm 0.4 \\
2.1 \pm 0.3\end{array}$ & Brown & $22 \pm .9$ & $95 \pm .7$ & $4.43 \pm 0.15$ & $4.00 \pm 0.23$ & $4.01 \pm 0.14$ \\
\hline 7 & Regular & Dry & $\begin{array}{l}1.7 \pm 0.2 \\
3.1 \pm 0.4\end{array}$ & Brown & $25 \pm .8$ & $92 \pm 1.8$ & $4.21 \pm 0.21$ & $4.00 \pm 0.32$ & $3.90 \pm 0.23$ \\
\hline
\end{tabular}

${ }^{*}$ RoM $=$ Rate of melting (\%), $\pm \mathrm{SE}$; ${ }^{*} 2 \mathrm{DoMW}=$ Draining rate of melted water $(\%), \pm \mathrm{SE}$.

* 3 In a scale of 0 to 5 with 5 being the best, \pm SE

Table 3. Quality of iced fish (C. mrigala) in new icebox under different storage period

\begin{tabular}{c|ccc|c|c|c|c|c|c|c}
\hline \multirow{2}{*}{$\begin{array}{c}\text { Period } \\
(\mathrm{d})\end{array}$} & \multicolumn{3}{|c|}{ Proximate Composition*1 } & Peroxide & $\begin{array}{c}\text { TVBN }{ }^{* 1} \\
\mathrm{mg} / 100 \mathrm{~g}\end{array}$ & PA & Color & Flavor \\
\cline { 2 - 5 } & Moisture & Protein & Lipid & Ash & & & \\
\hline 0 & 77.10 & 19.32 & 0.54 & 1.00 & 4.62 & 14.06 & Excel & Shiny & Fresh \\
1 & 78.03 & 20.10 & 0.56 & 0.95 & 5.15 & 16.09 & Excel & Shiny & Fresh \\
3 & 77.87 & 18.20 & 0.45 & 0.81 & 7.20 & 22.04 & Excel & Shiny & Fresh \\
5 & 76.24 & 17.88 & 0.42 & 0.74 & 9.04 & 30.69 & Good & LoB & Fresh \\
\hline 7 & 75.34 & 17.25 & 0.36 & 0.78 & 10.89 & 33.87 & Good & LoB & Fresh \\
\hline
\end{tabular}

*1 Mean of 3 trails, PA = Physical appearance; LoB = Loss of brightness 
Table 4. Changes in organoleptic qualities of $P$. sopore during ice storage in low cost ice box

\begin{tabular}{c|l|c|c|c}
\hline $\begin{array}{c}\text { Day of } \\
\text { storage }\end{array}$ & \multicolumn{1}{c|}{ Organoleptic characteristics } & $\begin{array}{c}\text { Average defect } \\
\text { point }\end{array}$ & Grade & $\begin{array}{c}\text { Overall } \\
\text { qualities }\end{array}$ \\
\hline 0 & $\begin{array}{l}\text { Fresh flavour; bright and shining appearance; } \\
\text { firm and elastic texture; clear eyes, red gills. }\end{array}$ & $1 \pm 0$ & A & Excellent \\
$1 \quad$ & $\begin{array}{l}\text { Fresh flavour; bright and shining appearance; } \\
\text { firm and elastic texture; clear eyes, red gills. }\end{array}$ & $1.2 \pm 0.1$ & A & Excellent \\
$2 \quad \begin{array}{l}\text { Fresh flavour; bright and shining appearance; } \\
\text { firm texture; clear eyes, reddish gills. }\end{array}$ & $1.3 \pm 0.2$ & A & Excellent \\
$4 \quad \begin{array}{l}\text { Some loss in brightness; slight loss of natural } \\
\text { flavour; bright, shining, iridescent eyes; reddish } \\
\text { gill; firm texture. }\end{array}$ & $2.2 \pm 0.1$ & A & Excellent \\
$6 \quad \begin{array}{l}\text { Some loss in brightness, slight loss of natural } \\
\text { flavour, bright, shining, iridescent eyes; firm } \\
\text { texture. }\end{array}$ & $2.4 \pm 0.2$ & A & Excellent \\
$8 \quad \begin{array}{l}\text { Slight loss in brightness, slight loss of natural } \\
\text { flavour, eyes dull; gill brownish; firm and elastic } \\
\text { texture }\end{array}$ & $2.5 \pm 0.3$ & A & Excellent \\
Loss of brightness; no flavour; sunken eyes; firm \\
and elastic texture.
\end{tabular}

\section{Organoleptic qualities iced $P$. sophore}

The results of the changes in organoleptic characteristics of iced $P$. sophore have been shown in Table 4. The average defect points (DP) of the fish on the first day was $1.0 \pm 0$, showing no loss of natural flavors and odour. The DP was gradually increased with the passing of storage period. On the $8^{\text {th }}$ day DP was quite good with a average DP score of $2.5 \pm 0.3$, but on the $10^{\text {th }}$ day DP raised to $3.2 \pm 0.2$, showing a slight deterioration of quality with loss of brightness and opaque eyes. But other characteristics were in acceptable limits. Organoleptic data indicated that the quality of $P$. sophore was good and acceptable up to $10^{\text {th }}$ day.

\section{Changes in the chemical and bacteriological properties of iced P. sophore}

Fig. 1,2 and 3 show the non-protein nitrogen (NPN), peroxide value (PV) and aerobic plate count (APC) of ice-stored P. sophore. Both NPN and PV are widely used chemical parameters to assess the freshness of fish. With an initial NPN value of 0.4 it reached to $1.6 \%$ in iced fish on $10^{\text {th }}$ day of storage (Fig. 1).

The PV less than $15 \mathrm{~m} . \mathrm{eq} / \mathrm{kg}$ of oil of postmortem fish body is considered acceptable (Gopakumer, 2002). In ice stored P. sophore, the initial PV values of $4.2 \mathrm{~m} . e q / \mathrm{kg}$ on the $1^{\text {st }}$ day was raised to $7.5 \mathrm{~m} . \mathrm{eq} / \mathrm{kg}$ on $8^{\text {th }}$ day but $11.56 \mathrm{~m} . \mathrm{eq} / \mathrm{kg}$ on $10^{\text {th }}$ day of storage (Fig. 2). Good quality fish should have a peroxide value quite less than 10. Peroxide value above 20 for any fish is considered rancid (Nowsad, 2007). 


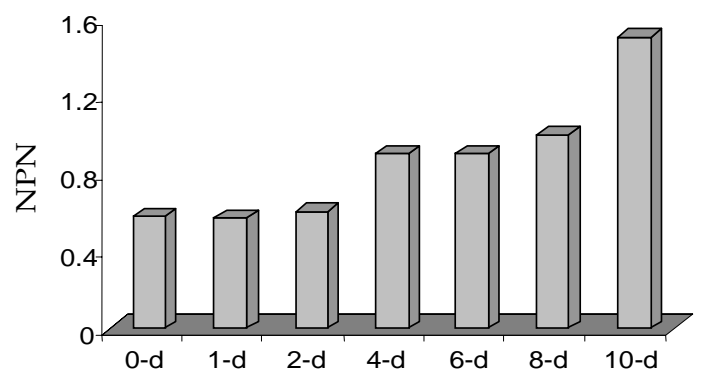

Fig. 1. Non-protein nitrogen (NPN) of iced P. sophore

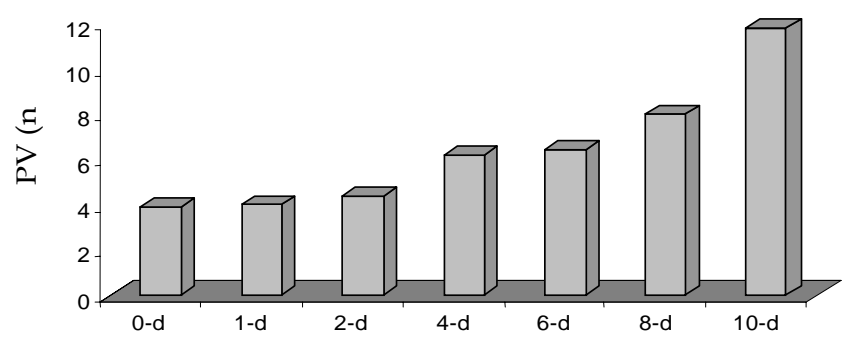

Fig. 2. Peroxide value (PV) of iced P. sophore

The aerobic plate count of iced P. sophore is shown in Fig 3. The initial bacterial load was $2.3 \times 10 \mathrm{cfu} / \mathrm{g}$, and the value was gradually increased to $6.0 \times 10 \mathrm{cfu} / \mathrm{g}$ on $4^{\text {th }}$ day, while $12.16 \times 10 \mathrm{cfu} / \mathrm{g}$ on the $10^{\text {th }}$ days of ice storage. The APC values were also within the acceptable microbiological limits for chilled or frozen fish.

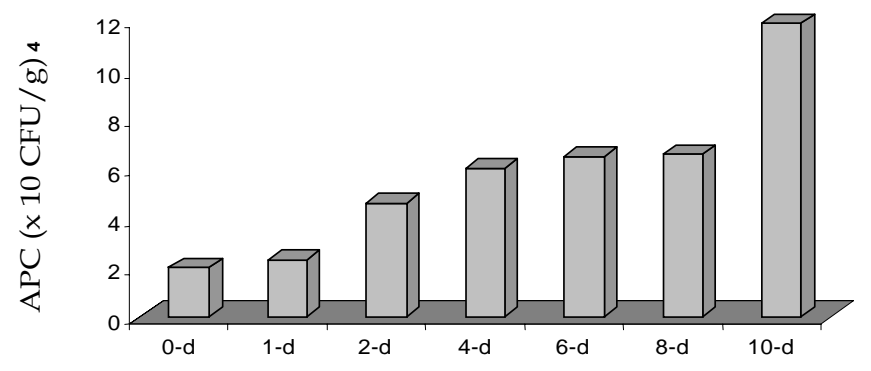

Fig. 3. Aerobic plate count (APC) of iced P. sophore

The icebox was field tested among the fishers and small-scale fish traders of Cox's Bazar and Kulierchar. The communities were trained to construct low-cost icebox and to adequately ice their fish. The efficacy (hardiness, ice melting rate, melted water discharge rate) and utility (low-cost, users' friendly) of the box at both the places (data not shown) has proved it as to be an effective ice box for preservation and transportation of iced fish at rural level. 


\section{ACKNOWLEDGEMENT}

The research was supported by the FAO through the Empowerment Project (BGD/97/017) during 2004-2005 and then by the Bangladesh Fisheries Research Forum.

\section{REFERENCES}

AMC. 1979. Analytical Methods Committee. Recommended General Methods for the Examination of Fish and Fish products. Analysts, 104: 434-450.

Collins, C. H. and Patricia, M. L. 1976. The gram-negative non-sporing rods. In: Microbiological Methods, Fourth ed. Butterworth and Co. (Publishers) Ltd. London, pp. 349-380.

DOF. 2007. Annual Report. Department of Fisheries. Matsaya Bhaban, Ramna, Dhaka.

Gopakumar, K. 2002. Post-mortem changes in fish and quality assessment. In: Textbook of Fish Processing Technology. K. Gopakumar (ed). Indian Council of Agricultural Research, New Delhi. 491p.

Howgate, P. A., Johnston, K. and Whittle, J. 1992. Multilingual Guide to EC Freshness Grades for Fishery Products. Torry Research Station. Food Safety Directorate, Ministry of Agriculture, Fisheries and Food, Aberdeen, Scotland.

Kabir. A. S. 2000. Studies on the post mortem changes of genetically improved farmed tilapia (Orepchromis niloticus) during ice storage. M. Sc. Thesis. Dept. of Fisheries Technology, Bangladesh Agricultural University, Mymensingh.

Islam, M. N. 1977. Chemical composition of some important marine fishes of Bangladesh and production of high quality fish meal. M. Sc. Thesis. Dept. of Fisheries Technology, Bangladesh Agricultural University, Mymensingh.

Nowsad, AKM. A. 2005. In: Low-cost Fish Processing in Coastal Bangladesh. BGD/97/017 Field Doc: 5/2005. Food and Agriculture Organization of the United Nations. 77 p.

Nowsad, AKM. A. 2007. Participatory Training of Trainers: A new approach applied in Fish Processing, Bangladesh Fisheries Research Forum, 328 p. 